\title{
The Capacious Bibliographical Practice of Conrad Gessner
}

\section{Citation}

Blair, Ann. "The Capacious Bibliographical Practice of Conrad Gessner." The Papers of the Bibliographical Society of America 111, no. 4 (2017): 445-68.

\section{Permanent link}

http://nrs.harvard.edu/urn-3:HUL.InstRepos:41376564

\section{Terms of Use}

This article was downloaded from Harvard University's DASH repository, and is made available under the terms and conditions applicable to Open Access Policy Articles, as set forth at http:// nrs.harvard.edu/urn-3:HUL.InstRepos:dash.current.terms-of-use\#OAP

\section{Share Your Story}

The Harvard community has made this article openly available.

Please share how this access benefits you. Submit a story.

\section{Accessibility}


Final author's manuscript of

Ann Blair, "The Capacious Bibliographical Practice of Conrad Gessner," Papers of the Bibliographical Society of America 111:4 (2017), pp. 1-24.

\section{The Capacious Bibliographical Practice of Conrad Gessner ${ }^{1}$}

I'm delighted to join you today at this annual meeting and to celebrate this year's new scholars and award recipients and especially those elected this year to honorary membership in recognition of their many contributions to the Society--R. Dyke Benjamin, D. W. Krummel, and Roger Stoddard. The work of new and longstanding practitioners of bibliography illustrates the tremendous range of a discipline which can span every field of endeavor that results in writing. Bibliography takes many forms and serves many purposes but is often insufficiently appreciated, perhaps particularly these days. Digital technologies seem to blur the boundaries between bibliography and parallel endeavors such as library catalogs or digital collections of text and many outside the scholarly fields assume that a general search engine can suffice to find anything without expert curation. As we ponder how to optimize the purposes and methods of describing books today, I'd like to illustrate the breadth of bibliography as it was practiced by Conrad Gessner (1516-65), who played a crucial role in expanding the purview of bibliography from manuscripts to printed books and from specific fields (mostly legal or ecclesiastical) to a universal scope. His Bibliotheca universalis (1545) was only printed in one edition, but was the object of two abridgments and three sequels in the sixteenth century and was widely cited as a model in bibliographies of many kinds for centuries afterward. ${ }^{2}$ In the first and largest of these volumes Gessner asserted the crucial role of libraries or institutions dedicated to the preservation of books and used his printed "library" to help in this cause by providing information which may seem unusual by the standards of modern bibliography, including mention of lost books, the locations of manuscripts, and excerpts from the paratexts of books. Our digital environment today makes it possible to consider returning to Gessner's original vision and expanding the purview of bibliography in some of these ways.

\footnotetext{
${ }^{1}$ Warm thanks to Martin Antonetti for the invitation and to everyone in attendance for the war reception and helpful comments. I am grateful to Anthony Grafton, Paul Nelles, and Mikhail Sergeev for invaluable comments on a draft of this written version. David Gants was a most patient editor and Dennis Duncan contributed crucial help in communicating with the Bodleian Library.

${ }^{2}$ Conrad Gessner, Bibliotheca universalis (Zurich: Froschauer, 1545); abbreviated as Bibliotheca in all further references. Followed by Conrad Lycosthenes, Elenchus scriptorum omnium (Basel: Oporinus, 1551); Conrad Gessner, Appendix bibliothecae (Zurich: Froschauer, 1555); Josias Simmler, Epitome bibliothecae Gesneri (Zurich: Froschauer, 1555); Josias Simmler, Bibliotheca instituta et collecta (Zurich: Froschauer, 1574) or Bibliotheca instituta in all further references; Johannes Frisius, Bibliotheca ... amplificata (Zurich: Froschauer, 1583). For a brief discussion of its further reception see my Too Much To Know: managing scholarly information before the modern age (New Haven: Yale University Press, 2010), 163-64.
} 
Conrad Gessner was the first to envision bibliography as "universal" spanning all the disciplines and all known learned books in his Bibliotheca universalis of 1545. Gessner started at age 26 this amazingly ambitious project to list all authors and their books written in Latin, Greek and Hebrew "extant and not, ancient and recent, learned and not, published and hiding in libraries." The title page further proclaimed that it was "a new work, necessary not only for forming private and public libraries, but very useful to all studious people to better shape the study of any art or science." 3 Gessner completed the work in three years - composing a text of almost 1,300 folio pages listing about 25,000 titles by 5,000 authors. ${ }^{4}$ As one who regularly climbed in the Alps in search of plant specimens, Gessner compared the experience to having returned from the tallest steep mountain. ${ }^{5}$ At a time when innovation was often couched as renovation, Gessner called attention to the novelty of his Bibliotheca in his detailed letter of dedication, but with suitable modesty: "If I did not bring this to perfection, I hope that I have started it nonetheless not too infelicitously. I have opened a way and given a great occasion to others, by which the rich and princes can found libraries, which are necessary for transmitting books to posterity."6 Gessner also announced here his principal goal-- to contribute to the transmission of books to posterity, notably by aiding the rediscovery and preservation of ancient learning.

While conscious and proud of innovating, Gessner was also unusually explicit in mentioning his sources and antecedents, providing a list of them in the front matter, in a pattern that he would repeat in the four volumes of his natural history published between 1551 and 1558. In the Bibliotheca Gessner identified five "Italian libraries furnished with Greek books whose catalogs I have owned or inspected," six works from which he reported excerpting material "here and there," and three "catalogs of writers" which he integrated wholesale into his own. The works Gessner declared having excerpted in parts

3 "Bibliotheca universalis, sive Catalogus omnium scriptorum locupletissimus, in tribus linguis, Latina , Graeca, et Hebraica: extantium et non extantium, veterum et recentiorum in hunc usque diem, doctorum et indoctorum, publicatorum et in Bibliothecis latentium. Opus novum, et non Bibliothecis tantum publicis privatisve instituendis necessarium, sed studiosis omnibus cuiuscunque artis aut scientiae ad studia melius formanda utilissimum." Bibliotheca, title page.

4 "Gaudeo profecto et gratias habeo immortali Deo, quod ex isto labyrintho, qui me circiter triennium intricavit, tandem evaserim." Bibliotheca, sig. [*6]r. For the most accurate count see Fiammetta Sabba, La "Bibliotheca universalis" di Conrad Gesner monumento della cultura europea (Rome: Bulzoni, 2012), 39.

${ }^{5}$ Wellisch, Conrad Gessner: A Bio-Bibliography (Zug: IDC, 1984), 50. "Nunc laetus aspicio labores meos, et meminisse iuvat: ut qui descendere per altissimum et praeruptum montem, cum in imo iam sunt, conversi mirantur, et ipsi de arduo itinere superato sibi congratulantur." Bibliotheca, sig. [*6]r. For a recent biography see Urs Leu, Conrad Gessner (1516-1565), Universalgelehrter und Naturforscher der Renaissance. Zurich: Verlag Neue Zürcher Zeitung, 2016, and 84-85 on mountains.

6 "[S]i non perfeci non infeliciter tamen, ut spero, inchoavi: viam aperui, et magnam alijs occasionem praebui, qua facile divites aut principes viri Bibliothecas instituant, libris ad posteritatem transmittendis necessarias." Bibliotheca, sig. *3r. 
focused on history (Maffei), the lives and writings of poets (Crinitus, Giraldi), lawyers (Rutilius, Fichard), and medical writers (Champier). ${ }^{7}$ These supplemented Gessner's principal sources: "On ecclesiastical writers" by the Church Father Jerome, "Gennadius on the same"; Joannes Fichard's "Two indexes of writers in law, canon and civil, from ancient and more recent jurisconsults, published in 1535," and Joannes Trithemius's "Catalog of ecclesisatical writers or famous men, in the third edition extended by the author, compiled in a period of seven years, down to 1494." printed edition of Trithemius in that he used first names of authors as the ordering principle and offered excerpts from tables of contents, as Trithemius did. But whereas Trithemius ordered his material roughly chronologically, to be accessed through an alphabetical index by first name, Gessner created a self-indexing work by ordering the entries themselves by the authors' first names. Gessner also added an index identifying the first names of authors from their last names, not present in Trithemius. ${ }^{9}$ Gessner explained that he copied over the material in these principal sources and added more-

${ }^{7}$ Gessner lists the Vatican Library in Rome, the Medici Library in Florence, the S. Salvatore Library in Bologna, and in Venice the libraries of Bessarion, scholar and cardinal, and Diego Hurtado a Mendozza, the imperial legate to Venice. The works from which he reported excerpting comprised: "Raphael Volaterranus, Anthropologia," which is tome 2 (books 13-23) of Raphael Maffei's Commentariorum rerum urbanarum libri XXXVIII (notably published Basel: Froben, 1530); "Bernardinus Rutilius, De vitis iursiconsultorum veterum" and "Io. Fichard, De vitis iurisconsultorum," contained in Jurisconsultorum vitae (Basel: Winter, 1537), discussed in more detail in the next note; "Petrus Crinitus, De poetis latinis" published in Crinito, De honesta disciplina (Basel: Henricpetri, 1532); "Lilius Gregorius Gyraldus, Historia poetarum," that is Giglio Giraldi, Historiae poetarum (Basel: Isengrin, 1545); and "Symphorianus Campegius, De scriptoribus medicinae" see Champier, Libelli duo... primus de medicine claris scriptoribus (Lyon: Jannot Deschamps, 1506). For a detailed study of Gessner's knowledge of Italian manuscripts and sources, see Sabba, La "Bibliotheca universalis," 57-92.

${ }^{8}$ Gessner relied on the 1526 edition of Jerome's works by Froben of Basel, as he mentions in his Bibliotheca, f. 322r-v. "Gennadius" probably refers to a book published in Basel by Cratander in 1529, usually cataloged under the first text it contained: Epiphanius, De prophetarum vita but which also included the Ecclesiasticorum vitae by Jerome and Illustrium virorum catalogus by Gennadius. Gessner refers to this edition in his entry on Gennadius of Marseille, a $5^{\text {th }}$-century cleric, in his Bibliotheca, f. 267v. For Fichard I expect he is referring to the indices mentioned here: Jurisconsultorum vitae veterum... Recentiorum vero, ad nostra usque tempora, per Joannem Fichardum. Ad haec indices duo locupletissimi omnium scriptorum... per Io. Nevizanum, Lud. Gomessium, \& Io. Fichardum collecti (Basel: Robert Winter, 1537).

${ }^{9}$ Gessner seems to cite Johannes Trithemius, Catalogus scriptorum ecclesiasticorum (Basel: Amerbach, 1494) though he also cited and used the 1531 Cologne edition printed by Petrus Quentell, 1531. For the index from last names to first names see Bibliotheca, sigs. A and B; this index is bound at the back of one of the copies digitized on E-rara, call numbers DrM3 containing Gessner's marginalia, but at the front of the other copy on Erara, ETH-Zurich Rar 9177. 
more authors, more books, and more elements of paratexts, including long quotations from prefaces or dedications explaining the contents of a book.

\section{Lost Books}

In listing his sources Gessner showed no awareness of what likely was the largest universal book list composed prior to his day: the Pinakes composed by Callimachus in the $3^{\text {rd }}$ century BCE to catalog the books of the library of Alexandria at a time when the Ptolemys strove to collect all Greek writings there. Although the Pinakes was cited as a model for library catalogs in the Byzantine and Arabic traditions some centuries later, Gessner was evidently not aware of its ever having existed. Callimachus features in Gessner's Bibliotheca, but only for his hymns, epigrams, and poems. ${ }^{10}$ Indeed ancient reference tools, of which there were likely many more than the few we know about today, fared especially poorly in the transmission from papyrus roll to parchment codex which was essential to the long-term survival of texts from ancient Greece and Rome. In selecting pagan works to copy early medieval scribes favored instead works which were part of the pedagogical, literary, or philosophical canon of the time. Bibliographical tools evidently did not catch the copyists' interest in the early middle ages; as a result these texts did not survive physically down to a period such as the Renaissance when there would have been cultural interest in recovering them.

The prior existence and almost complete loss of an ancient Greek universal bibliography would not have surprised Gessner if he had learned of it. Like other humanists he was keenly aware of the tremendous loss of ancient writings and devoted much of his life to aiding in their recovery and diffusion. One humanist's estimate of the survival rate of ancient texts seems reasonable enough by today's standards too: in 1494 Pietro Bembo surmised that one ancient Greek text in one hundred had survived to his day. ${ }^{11}$ By Gessner's time the humanist endeavor of scouring libraries for long forgotten medieval copies of ancient works had been underway for some two hundred years. Spectacular finds like Petrarch's rediscovery of Cicero's letters to Atticus in 1345 or Poggio Bracciolini's of Lucretius's De natura in 1417 had become increasingly unlikely. The recovery of Greek works was slower and still underway in the early sixteenth century, to which Gessner himself contributed the editiones principes of Aelian's natural history and

${ }^{10}$ Bibliotheca, ff. 160r-v. On the Pinakes see Lionel Casson, Libraries in the Ancient World (New Haven and London: Yale University Press, 2001), 38-41.

11 "How much of their literature did the Greeks lose since, at the time of their misfortunes, the Latins became so neglectful of these matters? What I am about to say is perhaps strange, but it is perfectly true. If we count the poets, orators, philosophers, and to put it briefly, past writers of works read by earlier generations of interested students, if we count all these, we shall find that perhaps we do not even have one per cent of them available to us now." Pietro Bembo, Oratio pro litteris graecis, ed. and trans. N. G. Wilson (Messina: Centro Interdipartimentale di studi umanistici, 2003), 36-37. I am grateful to Aaron Shapiro for this reference; see Shapiro "Renaissance cryptophilology: Scholars, poets, and the pursuit of lost texts." PhD Dissertation Boston University, Comparative Literature and Classical Studies, 2014, 49-50. 
the meditations of Marcus Aurelius. ${ }^{12}$ In the 1540 s Gessner was excited to call attention to late and little-known Greek works and those which survived only in excerpts in anthologies. Gessner's first folio publication, two years before the Bibliotheca, was an important contribution to the project of humanist recovery and the object of a dozen later editions or adaptations: an edition from multiple manuscripts, with facing Latin translation, of the collection of sententiae by the $5^{\text {th }}$-century Greek compiler Stobaeus. ${ }^{13}$ Gessner explained the crucial role of that work and others like it as sources for his Bibliotheca: "In addition [to compiling the work] I excerpted the lists of names I observed of ancient authors whose writings survive in part or not at all, from the Greek dictionary of the Suda, Athenaeus's Deipnosophistae, the Gnomology of Stobaeus, Greek epigrams ... and a few others from some other sources. I always noted with perhaps excessively pedantic diligence any names mentioned in these works while reading them." "In Stobaeus and other similar works Gessner gathered up what could be known about authors from whom little or nothing survived and diffused it in the Bibliotheca in order to encourage scholars to seek out and rescue any such texts or fragments that they might find "hiding in libraries."

The painstaking work that Gessner describes of collecting fragments and references to them has remained a central activity in classical scholarship down to the present, but bibliographies focused on the era after printing have generally neglected "lost books." 15 These were the object of one careful study by Joseph-Marie Quérard (1797-1865) published posthumously in 1872 by Pierre Gustave Brunet (1805-96). ${ }^{16}$ Specialized

${ }^{12}$ Gessner ed. and tr., Aelianus. Opera (Zurich: Andreas and Jakob Gessner, 1556) and Gessner ed., Marcus Aurelius Antoninus. De vita sua. Marini de vita Procli (Zurich: Andreas Gessner, 1559). On the latter see Mikhail Sergeev, "From Search for Manuscripts to Title-page Layout: On the History of Marcus Aurelius's Editio princeps," conference paper delivered at the Renaissance Society of America (2016) and forthcoming in print.

${ }_{13}$ Gessner, Stobaeus, Sententiae ex Thesauris Graecorum (Zurich: Froschauer, 1543). For the later editions see Wellisch, 40-43. Gessner went on to variously edit, translate and comment on a number of other Greek works; for more details see my "Printing and Humanism in the Work of Conrad Gessner," Renaissance Quarterly, 70:1 (2017), 1-43, p. 2-3.

14 "Caeterum nomenclaturas authorum veterum quorum scripta vel nulla, vel partim non extant, ex Dictionario Graeco Suidae, Athenaei Dipnosophistis, Gnomologio Stobaei et Epigrammatibus Graecis ... necnon aliis quibusdam observatas excerpsi. Et nimium exquisita forte aut curiosa diligentia, quaecunque inter legendum citata nomina occurrebant, statim annotavi..." Bibliotheca, sig *3r-v.

${ }^{15}$ On collecting classical fragments see Glenn Most ed., Collecting fragments $=$ Fragmente sammeln (Göttingen: Vandenhoeck \& Ruprecht, 1997) or Oliver Primavesi and Katharina Luchner eds., The presocratics from the Latin Middle Ages to Hermann Diels (Stuttgart: F. Steiner, 2011).

${ }^{16}$ J.M. Quérard, G. Brunet, Livres perdus et exemplaires uniques (Sala Bolognese : A. Forni, 1984; reprint of edition of Bordeaux: Lefevbre, 1872). 
studies of individual authors may also point out lost works of that individual. ${ }^{17}$ But the national catalogs of printed books launched in the early twentieth century and which form the basis for many of our current digital tools and corpora took no interest in lost books. ${ }^{18}$ With the new power of collective online catalogs and portals in this century information about Quérard's lost books can be updated: some items turn up readily; others should no doubt still be recorded as lost, with the caveat that a "lost book" may also be one that one was never actually produced. ${ }^{19}$ In addition we may now know of hitherto unrecorded "lost books" and we also know from experience that books can be found which we didn't even realize were lost (such as the case of otherwise unknown religious pamphlets discovered in 1989 in the floorboards of an early modern house in Delft). ${ }^{20}$ The theme of loss which has long featured in studies of ancient books and libraries deserves more attention for later periods as well. Some recent studies in book history have focused specifically on the causes and circumstances of loss, intentional and accidental, which are fundamental to understanding the objects and texts which have survived as a subset of those that once existed. ${ }^{21}$

For humanists fearful of loss, whether of newly recovered ancient texts or their own writings, printing seemed to promise increased odds of preservation. Conrad Lycosthenes, in introducing an abridgment of Gessner's Bibliotheca in 1551 noted for example: "Today the art of typography, granted by God to the men of our time for the preservation of letters to posterity, will supply authors of every kind. By this art as much is produced in one day by one man even unskilled in letters, as it was barely possible to produce in a whole year by several men with the speediest quill."22 The redundancy generated by all those printed copies was a welcome safeguard against loss. Even if the rate of preservation of printed books has been estimated at just 2-3\% for incunabula, or even as low as $1 \%$ for the period including the $16^{\text {th }}$ century, those rates applied to the much greater output of printed volumes and resulted in many more surviving books than from the period before printing. ${ }^{23}$ Many factors specific to each book of course loom

\footnotetext{
${ }^{17}$ For lost books by Gessner see Wellisch, 113-114.

18 James Raven, What is the history of books? (forthcoming Polity Press, 2018), 58ff.

${ }^{19}$ For example Le caquet des femmes du fauxbourg Montmartre, 1622 is available in the digital BnF catalog, though it is listed in Quérard, Brunet, 15.

${ }^{20}$ Andrew Pettegree, The Renaissance Book (New Haven and London: Yale University Press, 2010), 333.

${ }^{21}$ Flavia Bruni and Andrew Pettegrees eds., Lost books: reconstructing the print world of pre-industrial Europe (Leiden: Brill, 2016); and James Raven ed., Lost libraries : the destruction of great book collections since antiquity lost libraries (Houndmills, Basingstoke, Hampshire: Palgrave Macmillan, 2004). See also Glen Dudbridge, Lost books of medieval China (London: British Library, 2000) for some fascinating parallels. 22 "Suppeditabit hodie autores omnis generis ars typographica, ad literas posteris conservandas nostrae tempestatis hominibus divinitus concessa, qua tantum una die ab homine etiam literarum imperito exprimitur, quantum vix toto anno a compluribus penna licet properantissima exarari esset possibile." Lycosthenes, Elenchus, sig. a[4]v-b1r. ${ }^{23}$ See Jonathan Green, Frank McIntyre and Paul Needham, "The Shape of Incunable Survival and Statistical Estimation of Lost Editions," The Papers of the Bibliographical
} 
large in explaining their fate-- cultural factors such as their commercial and symbolic value, whether they were forbidden or not, and whether their purpose at the time was ephemeral or long-term - and physical ones such as size and binding as per Roger Stoddard's dictum that "bigger books linger longer; little books last least." ${ }^{24}$ But books also survived differentially depending on the longevity of institutions that owned them, including churches, cities, states, and families across the social spectrum but especially at the upper echelons. ${ }^{25}$

\section{Libraries}

Gessner's main point in his long dedication of the Bibliotheca was to extol not printing but libraries as crucial to the transmission of learning into the future. The Bibliotheca universalis is often portrayed as a response to printing: Gessner innovated crucially over his sources like Fichard and Trithemius by providing publication information for many books - including place and date of publication, format and number of sheets. He also relied for his information on the "catalogs of printers of which I sought out many from various regions," some of which he printed in the Pandectae of 1548, offering modern readers a rare glimpse of a kind of source which has rarely survived. ${ }^{26}$ Indeed a recent article has pointed out that Gessner's motivation to compose the Bibliotheca originated in his compilation of a catalog of the publications of the Zurich printer Froschauer in preparation for travelling with him to the Frankfurt book fair in $1543 .{ }^{27}$ Gessner also referred to the role of printing in preservation, but in the same breath complained of the

Society of America, 105: 2 (June 2011), 141-175, p. 144. For discussion of survival rates for medieval manuscripts, see David d'Avray, "Printing, mass communication, and religious reformation: the Middle Ages and after," in Julia Crick and Alexandra Walsham eds., The Uses of Script and Print, 1300-1700 (Cambridge: Cambridge University Press, 2004), 50-70, pp. 52-61.

${ }^{24}$ As quoted in Michael Suarez, "Hard Cases: Confronting Bibliographical Difficulty in Eighteenth-Century Texts," in The Papers of the Bibliographical Society of America, 111:1 (2017), 1-30, p. 23.

${ }^{25}$ See Green, McIntyre, and Needham, 152: "books do not survive independently of one another."

26 "Materiam operis undecunque corrasi: ex catalogis typographorum, quorum non paucos diversis e regionibus conquisivi." Bibliotheca, sig. *3r. On Gessner and printers see Urs Leu, "Die Bedeutung Basels als Druckort im 16. Jahrhundert," in Basel als Zentrum des geistigen Austauschs in der frühen Reformation, ed. Christine Christ-von Wedel, Sven Grosse, and Berndt Hamm (Tübingen: Mohr Siebeck, 2014), 53-78; and Paul Nelles, "Reading and Memory in the Universal Library: Conrad Gessner and the Renaissance Book," in Ars Reminiscendi: Mind and Memory in Renaissance Culture, ed. Donald Beecher and Grant Williams (Toronto: Centre for Reformation and Renaissance Studies, 2009), 147-169.

${ }^{27}$ Paul Nelles, "Conrad Gessner and the Mobility of the Book: Zurich, Frankfurt, Venice (1543)," in Books in Motion in Early Modern Europe. Beyond Production, Circulation and Consumption, ed. Daniel Bellingradt, Paul Nelles, and Jeroen Salman (Cahm: Palgrave Macmillan, 2017), 39-66. 
impact of printing and called for libraries to counteract it: "Although the typographical art seems to have been born for the conservation of books, most of the time nonetheless in our time the foolish and useless writings of men are edited, to the neglect of the old and better ones: for which reason there is a need for libraries at least for manuscript books."28 Gessner was well aware that printing alone could not solve the problem of transmitting ancient works: in the marketplace they were swamped by cheaper, less important works. And books did not survive all by themselves. Gessner knew that well enough since in another work he actually recommended cutting and pasting from printed books in order to save the labor of copying from them to index them for example. ${ }^{29}$ [See Figure 1] In offering this advice Gessner noted that two copies of a book were needed, so as to be able to cut and paste from the text on both the recto and the verso of a page, but he showed no concern for retaining a third, undamaged copy for later use. In fact, Gessner probably mostly used in this way books that had already lost their commercial value, e.g. in being marked up as printer's copy for making a later edition.

Gessner worried especially about the fragility of libraries. He bemoaned the loss of the famous library of Alexandria with 700,000 volumes (by which were meant scrolls, not necessarily whole works), and of many lesser known libraries like the 30,000 books belonging to the grammarian Tyrannion, or even just the two books of his composition that Galen reported losing in a fire at the temple of Peace. [See Figure 2] And Gessner lamented recent losses, such as the pillaging of Buda, which occurred "in the memory of our fathers" (in 1526 after the battle of Mohacs) and destroyed the great library formed there by Matthias Corvinus. Then Gessner exclaimed: "But what now remains of all these glorious libraries except an empty reputation? ... So many and such precious books in every philosophy were gradually lost, some consumed by flames or the tumult of war, some by age itself corrupted by worms or filth, many dissipated by negligence and the hatred of barbarians for learning." 30 What could be done? Gessner's new solution in the Bibliotheca universalis was to gather the knowledge about books from which others could build great libraries.

Gessner used dedications throughout his prolific career to praise wealthy merchants like Johann Jakob Fugger, diplomats like Diego Hurtado de Mendoza, or cities like Augsburg for creating great collections of books and to encourage them publicly to grant scholars

28 "Quamvis enim ars typographicae librorum conservationi nata videatur, ut plurimum tamen nostri temporis hominum nugae et inutilia scripta, vestustis et melioribus neglectis in lucem eduntur: quare pro manuscriptis saltem libris opus est Bibliothecis." Bibliotheca, $\operatorname{sig} * 3 \mathrm{r}$.

${ }^{29}$ Gessner, Pandectae (Zurich: Froschauer, 1548), fol. 20r. For more discussion see my Too Much To Know, 96, 212-25.

30 "Quid vero nunc ex omnibus illis tam gloriosis bibliothecis praeter inanem famam reliqui est? ... Quandoquidem igitur tot et tam pretiosi in omni philosophia libri paulatim amissi sunt, partim flammis aut bellorum tumultibus consumpti partim ipsa vetustate tineis ac situ corrupti, plurimi vero dissipati negligentia et odio in literas barbarorum..." Bibliotheca, sig. *2v. 


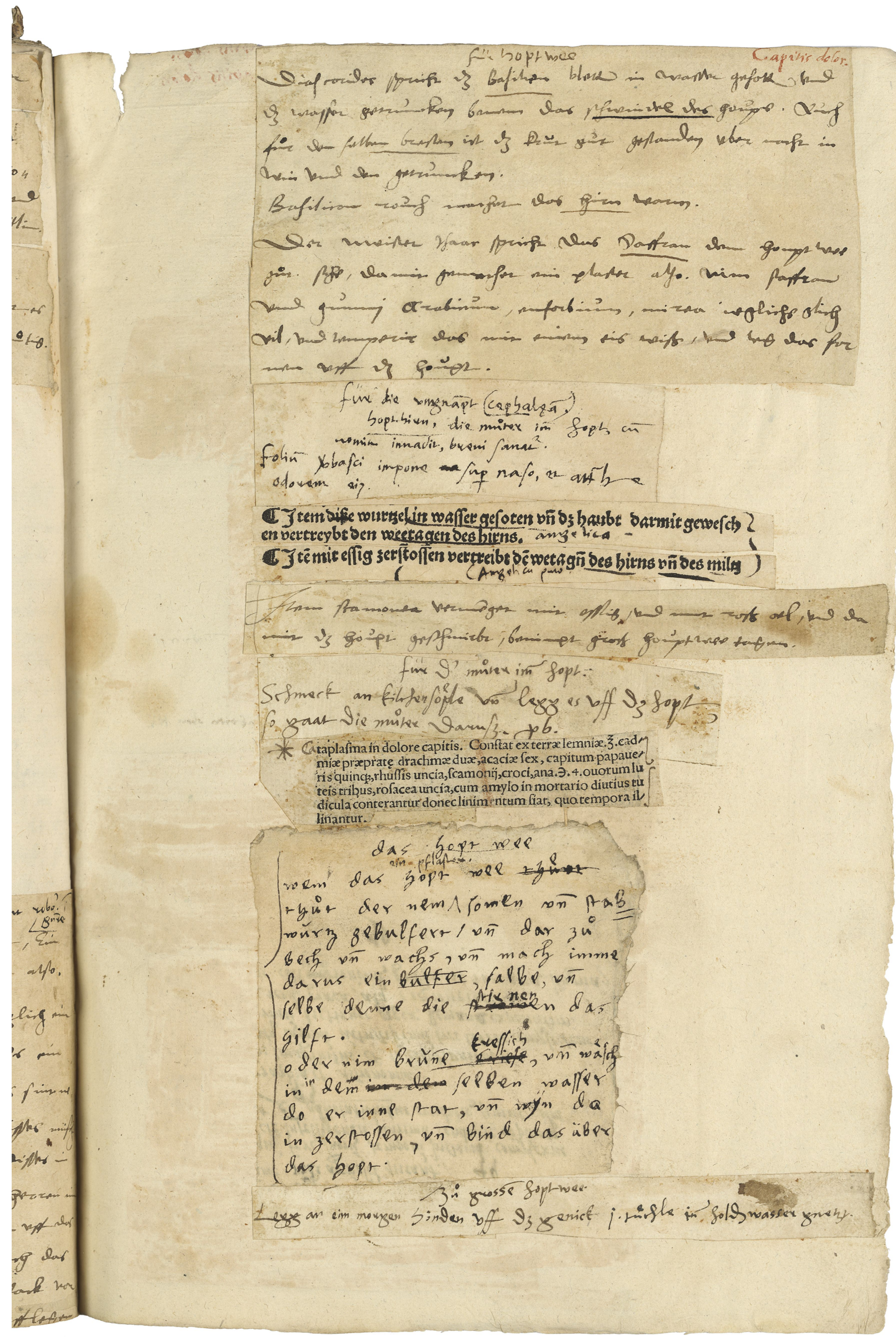

Figure 1: A page from Gessner's unpublished "Thesaurus practice medicinae." Zentralbibliothek Zürich, Ms 204a, f. 47r. 


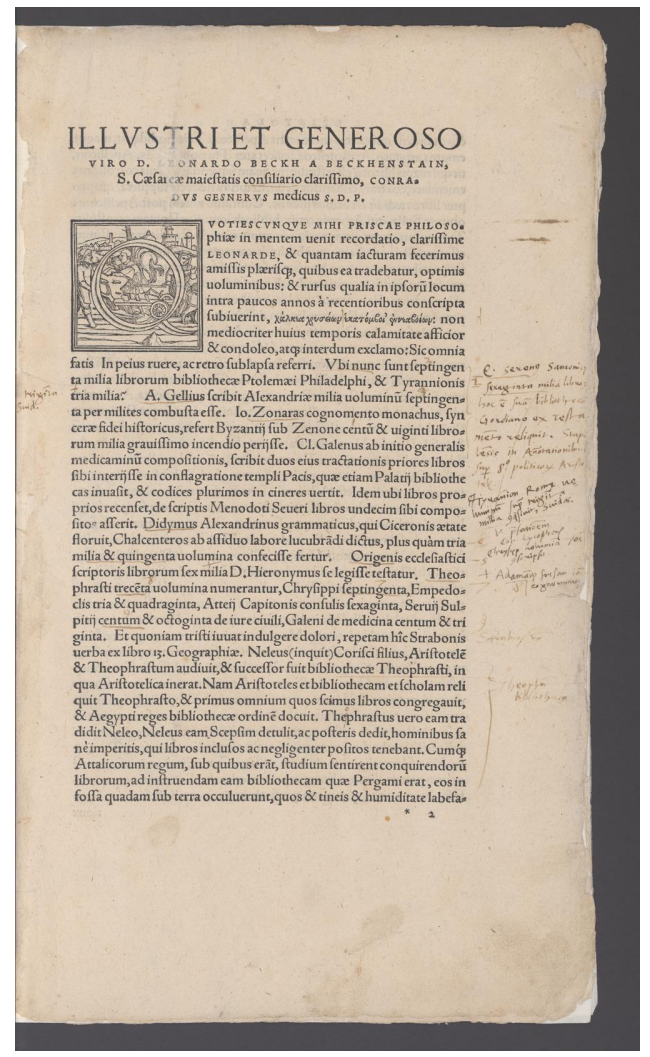

Figure 2: Conrad Gessner, Bibliotheca universalis (1545), beginning of the dedication. This copy from the Zentralbibliothek in Zurich was Gessner's own copy which he annotated heavily. In these opening lines where he bemoans the many lost libraries he corrected 3000 to 30,000 in the left margin as the size of the library of the Greek grammarian Tyrannion, following information in the Byzantine Suda. 
like him access to their exceptional holdings. ${ }^{31}$ Gessner dedicated his Bibliotheca and addressed his exhortation on libraries to one Leonard Beck von Beckenstein, counselor to the Holy Roman Emperor, to whom he had already dedicated a smaller work of neo-latin poems by Antonio Telesio five months earlier. ${ }^{32}$ On that occasion Gessner offered fulsome praise for Beck's virtue and reputation, although it appears that Gessner did not know him personally. "Rumor has it that you spend your fortune generously, not as the majority of the rich usually do, only to accumulate wealth or to squander it recklessly for useless or forbidden purposes. ... The glory that redounds to you stems in no small part ... from the fact that you lead a frugal life and embrace good letters and favor the learned with extreme diligence." ${ }^{33}$ Gessner singled out Beck's library for specific praise: "We know this most certainly from the letters of friends, that your Library is full to a near miraculous extent of innumerable and remarkable books: which we see as an enormous benefit to the republic of letters and all posterity." 34 Gessner clearly planned his two dedications to Beck in 1545 as a pair, closing in February with the announcement of the Bibliotheca: "You will await shortly our Bibliotheca or Catalog of all writers which is to be printed within four months, God willing." 35 The Bibliotheca indeed appeared in July of that year, complete with an exceptional full page print of Beck's coat of arms.

Although Gessner offered one more short dedication to Beck in 1555, we have no further evidence about Beck's library or his relationship to Gessner. ${ }^{36}$ It seems most likely that Gessner's appeal to Beck to build a great library to benefit posterity and the scholars of his day did not yield the desired results.

Thanks to print a personal dedication to one man in the Bibliotheca also became an open letter to all readers, encouraging each according to his means to support libraries and the

${ }^{31}$ For a table and discussion of Gessner's dedications see my "The dedication strategies of Conrad Gessner," in Professors, Physicians and Practices in the History of Medicine: Essays in Honor of Nancy Siraisi, ed. Gideon Manning and Cynthia Klestinec (Cham: Springer, 2017), 169-209.

${ }^{32}$ Gessner, Antonii Thylesii. Opuscula aliquot (Basel: Oporinus, 1545). On Beck's ownership of Greek manuscripts, see Alfredo Serrai, Conrad Gesner, ed. Maria Conchetti (Rome: Bulzoni, 1990), 90.

33 "Fama fert, te fortunis tuis liberaliter uti, neque ut maior pars divitum solet, congerendis tantum opibus inhiare: neque temere, vel ad inutiles, vel etiam vetitos usus eas dilapidare. ... Accedit gloriae tuae non exigua pars, quod luxu et ocio in tanta occasione post habitis [sic for posthabitis], vitam frugalem degas, et bonas amplectare literas, et literatis summopere faveas." Thylesii opuscula, sig. a3v.

34 "Hoc sane certissimum ex literis amicorum habemus, Bibliothecam tibi esse innumeris et egregiis libris ad miraculum usque instructam: quod quidem in rempublicam literariam et omnem posteritatem, beneficium ingens interpretamur." Thylesii opuscula, sig. a4r. 35 "Expectabis autem brevi Bibiothecam nostram, sive Catalogum scriptorum omnium, intra quatuor menses, Deo favente, a praelo absolvendum." Thylesii opuscula, sig. a5r. I am using the date listed at the end of each dedication, following the format of a letter, as a proxy for the publication date of the book.

${ }^{36}$ This third dedication appears in the foldout-table in Gessner's Mithridates (Zurich: Froschauer, 1555). 
finding of valuable books to stock them. To all those readers Gessner offered throughout the Bibliotheca details about unpublished works and specific advice on where to find the manuscripts. This information, akin to that provided today in book search engines and collective online catalogs, would be useful to scholars looking for a manuscript to read or publish but also to the princely owners of great libraries looking for a manuscript to have copied or purchased. This information about the locations of manuscripts was kept up to date and included in the sequels to Gessner's Bibliotheca, even though those later volumes explicitly worked in other ways to trim down the size of Gessner's material. An Appendix published by Gessner in 1555 included 2000 new authors with succinct entries for each and after Gessner's death two more editions of the Bibliotheca appeared in 1574 and 1583, each longer than the next, so that the edition of 1583 listed about 9000 authors, three times as many as were listed in $1545 .{ }^{37}$

We have unusual evidence of the interests of one notable contemporary reader in a copy of the 1574 Bibliotheca instituta at the Bodleian Library which contains annotations throughout by the English polymath John Dee (1527-1608), an avid book collector who assembled one of the largest libraries in Elizabethan England. ${ }^{38}$ Dee used underlining to signal passages of interest while reading Simmler's expanded edition of Gessner's Bibliotheca and added manuscript comments in the margins. Dee added authors who did not feature in the printed text and added details to some entries; in a number of these cases Dee listed the Suda as his source. Dee also made some corrections (e.g. noting that Geoffrey of Monmouth translated the divinations of Merlin into Latin from British rather than English) and he copied into the margin observations he found of interest ("Cyprianus [a bishop of Carthage] wrote in Latin"). ${ }^{39}$ As one might expect Dee underlined every mention of himself; he also added details from his personal experience, noting in the margins for example that he met Ulisse Aldrovandi when visiting in Bologna in 1563, received a visit at his home in Mortlake from the Pole "Ioannes Lasicius" (i.e. Johannes a Lasco, 1499-1560), and corresponded with various authors (e.g. Nicolaus Stopius or the Englishman Clemundus whose commentary on Pliny Dee tried unsuccessfully to urge Oporinus to publish). ${ }^{40}$

37 Josef Hejnic and Vaclav Bok, Gesners europäische Bibliographie und ihre Beziehung zum Späthumanismus in Böhmen und Mähren (Vienna: Böhlau, 1989), 14.

${ }^{38}$ For an entry into Dee and his context see Frederic Clark, "Dividing Time: The Making of Historical Periodization in Early Modern Europe, c.1500-1750," PhD Dissertation in History, Princeton University, 2014, 65-68.

${ }^{39}$ Bibliotheca instituta, Bodleian Library shelfmark Arch. H c.7 (further references will mention only this call number), p. 31: "Ambrosius Merlinus Britannus ... scripsit ... Divinationum ... libros quos Galefridus Monemuthensis transtulit ex anglice [in ms: brytannico] in Latinum." And p. 106: "Latino sermone scripsit Cyprianus" written out in the margin accompanies a strong underline of the corresponding printed text "Latino sermone."

${ }^{40}$ Arch. H c.7: p. 681 (Ulysses Aldrovandi), p. 228 (adding onto the mention of Lasicius Polonus at the end of the entry for Georgius Rheticus: "Invisit me iste Lasicius Mortlaci; ut ipsius Rami testimonio constare potest; et eius ad me epistola"), 526 (Nicolaus Stopius, noting: "Huius ad me variae epistolae. Quo familiariter Venetijs usus sum anno 
Most strikingly Dee was consistently attentive to the whereabouts of manuscripts by underlining the information provided in print and adding information of his own. Dee's annotations of Simmler's edition of 1574 also prompt comparisons between that edition and Gessner's original Bibliotheca. We can watch the layers of attention devoted by Gessner, Simmler, and John Dee to the question of where to find interesting manuscripts, typically of ancient texts. In one case Simmler even added an entry for someone who was not an author, but a notable collector of Greek and Latin manuscripts "whom we will name in several places": the French royal counsellor Henri de Mesmes. ${ }^{41}$ In a simple case Dee underlined the information, carried over from the Bibliotheca of 1545, that Demetrius Cydonius's translation of a sermon of Aquinas into Greek was in the Vatican Library. In other cases the information about location that caught Dee's attention was new to the edition of 1574: for example that the Greek letters of Epictetus Phryx were in the Medici library in Florence or, rather less helpfully of the annals of Heliconius, "I hear they are extant in Italy." 42 Information about locations was clearly carefully updated between the editions of the Bibliotheca in 1545 and 1574. In 1545 Gessner noted that he seen the "De mysteriis" of Iamblichus in the library of San Salvatore in Bologna and that it was reported in the library of Diego de Mendozza in Venice (both of which were on Gessner's list of library catalogs consulted). In the abridgment of 1551 those references were dropped, leaving only the more general statement (present in 1545 too) that Greek manuscripts of the work were held in "many Italian libraries." In 1574 Simmler followed the formulation of 1551 but added some new information, that "all these Greek manuscripts are held in the library of the King of France" and that he had heard of letters and an arithmetic by Nicomachus extant "somewhere."43 Also new to 1574 were references to manuscripts owned by M. Dresserus, which Dee regularly underlined (e.g.

1563”), 132 (Clemundus Anglus, adding “J.D. transmissi erant ad Oporinum imprimendi. Mihique supplicavit D. Caius Medicus ut Oporinum memorem redderem impressionis instaurandae. Quod dum feci anno 1563. respondit Oporinus pecunias etiam usui relictas esse Testamento.”). This is presumably John Claymond (1468-1537), whose 20 volumes of commentary on Pliny were never published; 16 of these volumes are still now in Basel where Claymond presumably sent them in the hope of having them published, e.g. by Oporinus. See Jonathan Woolfson, "John Claymond, Pliny the Elder and the Early History of Corpus Christi College Oxford," English Historical Review 112: 448 (1997), 882-903.

41 "Henricus Memmius VC consiliarius regius et libellorum supplicum magister in Gallia. Plurimos veteres auctores manuscriptos Graecos et Latinos collegit, quorum aliquot suis locis nominavimus." Bibliotheca instituta, 1574, 279. Dee's copy shows a faint marginal line against that entry, which appears to an annotation.

42 Bodleian Arch H.c.7, 158 (Demetrius Cydonius), and 270: "Heliconius Sophista Byzantius, annalium compendium scripsit, ab Adamo usque ad Theodosium magnum lib. 10. Suidas. Audio extare in Italia."

43 "Iamblichus ... scripsit librum de mysteriis ... qui Graece servatur in multis Italiae bibliothecis. ... Omnia haec manuscripta Gr. servantur in bibliotheca Regis Gallorum. Audio etiam alicubi servari eiusdem librum de Nicomachi arithmetica, et epistolas." Bibliotheca instituta, 327. Compare with Bibliotheca universalis, 368v-369r. 
in entries for Henricus de Urimaria, Ioannes Hagen, or Joannes Mandevyle). ${ }^{44}$ This was presumably Matthaeus Dresser (1536-1607), professor of eloquence then of Greek and Latin at Leipzig and a prolific author, though I am not aware of any others (contemporaries or historians) commenting on his library.

In addition to underlining Dee also added notes in the margin. In some cases he just repeated printed information, perhaps in order to return to a possible "action point" of special interest. For example he was quite interested in the notice for Pappus of Alexandria, added in the edition of 1574, that his 14 books of astronomy were in the library of Petrus Ramus; Dee underlined it and wrote in the margin "Bibliotheca Rami."45 [Figure 3] Ramus had recently been killed on St Bartholomew's Day in 1572 and perhaps Dee hoped to track down the manuscript. Some of Ramus's manuscripts have found their way into libraries, including this manuscript of Pappus now in the Bibliothèque nationale de France which was scribed by Ramus's assistant Nicolas de Nancel; Nancel recalled this manuscript in particular in his biography of Ramus. ${ }^{46}$ Alongside the entry for Hugutio, the medieval canon lawyer (whom Gessner lists as Hugotio), John Dee added: "there exists a remarkable treatise in manuscript on metals by someone named Hugutio." ${ }^{47}$ [Figure 4] In this case Dee's note raised the problem of identifying the author as well as of locating the manuscript.

In a new entry in 1574 for "Petosiris" Dee underlined the author's name, and the locations of "his book to king Necepso" in the "bibliotheca Carpensi et S. Angeli" and of his astrologica owned by Ioannes Sambucus. ${ }^{48}$ The Bibliotheca's claims about book locations could prove long lived--the first of these was repeated for example in 1718: "Petosiris king of Egypt whose book to King Necepso is in the Bibliotheca Carpensis et S. Angeli" but with a different source: "as attested in Reinerus Reineccius Hist. Juliae

${ }^{44}$ Bodleian Arch H.c.7, 282 (Henricus de Urimaria), 377 (Joannes Hagen), 393 (Mandeville).

${ }^{45}$ Bodleian Arch H.c.7, p. 540; cf. Bibliotheca 1545, f. 535r.

${ }^{46}$ This manuscript (Fonds Grec 2368) is mentioned in A.P. Treweek, "Pappus of Alexandria, The manuscript tradition of the Collectio Mathematica." Scriptorium 11, no. 11-12 (1957), 195-233, p. 202. For Nancel's mention of it, see Peter Sharratt ed. and tr., "Nicolaus Nancelius, Petri Rami Vita," Humanistica Lovaniensia 24 (1975), 161-277, p. 204-5.

${ }^{47}$ Bodleian Arch H.c. 7, 307: "Hugutionis cuiusdam extat egregius tractatus de re metallica. liber manuscrip."

${ }^{48}$ Sambucus is also mentioned as having owned a manuscript of Theodorus Duca Lascaris: "Exemplar graecum V.C. Ioannes Sambucus Ioanni Leuvenclaio transmisit," new in 1574 and underlined by Dee; Bodleian Arch H.c.7, 651. Indeed a recent study has noted Sambucus's generosity in lending manuscripts from his collection to fellowhumanists, including Joannes Leunclavius; see Arnoud Visser, Joannes Sambucus and the Learned Image. The Use of the Emblem in Late-Renaissance Humanism (Leiden: Brill, 2005), 40. 


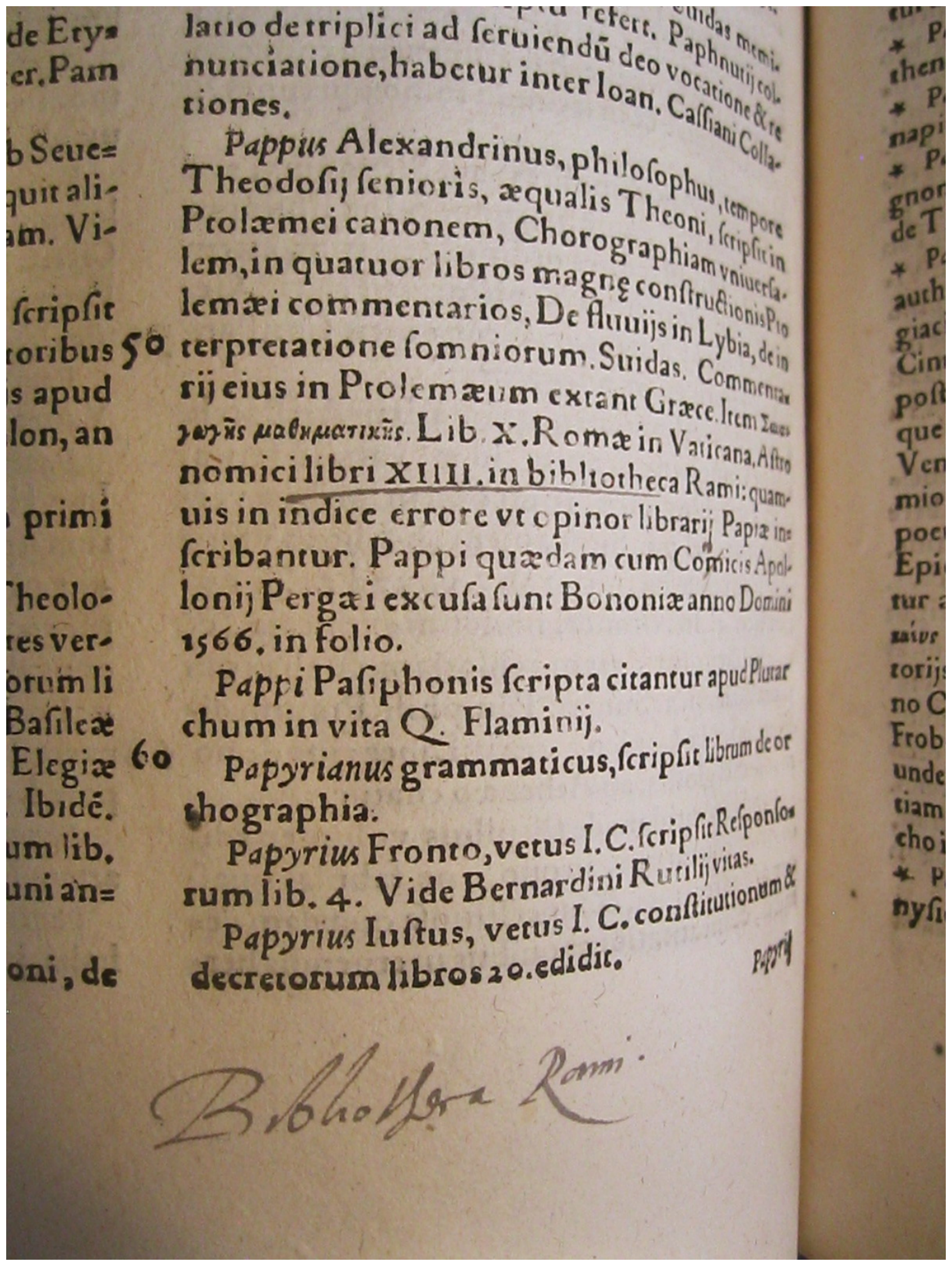

Figure 3: Josias Simmler, Bibliotheca instituta (Zurich: Froschauer, 1574), Bodleian Arch H.c.7, p. 540. 


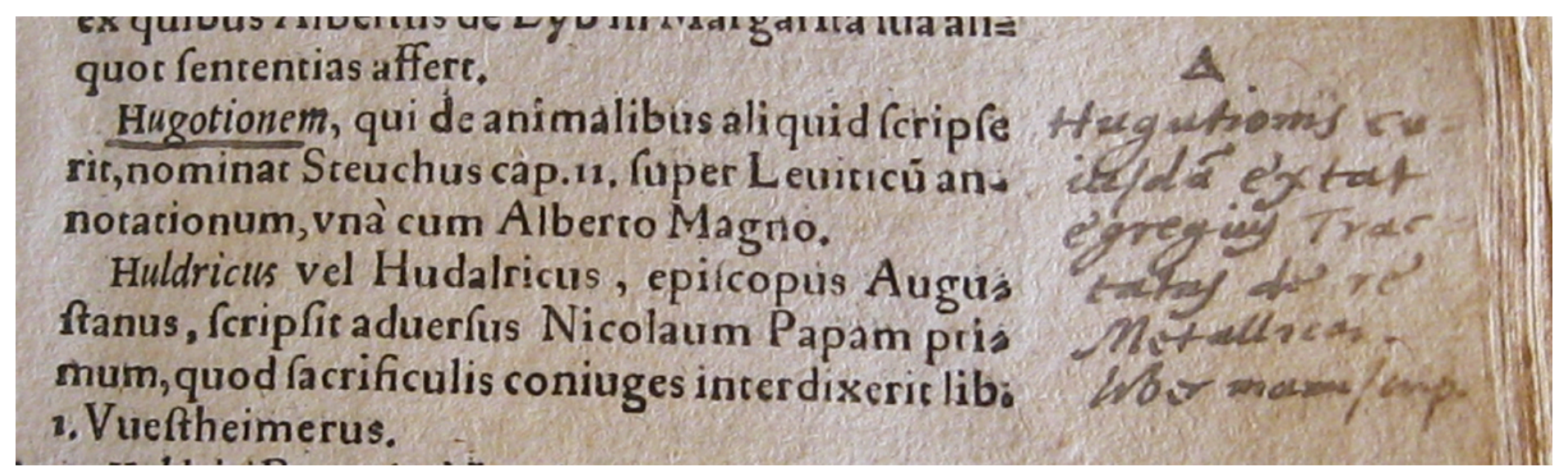

Figure 3: Josias Simmler, Bibliotheca instituta (Zurich: Froschauer, 1574), Bodleian Arch H.c.7, p. 307 
parte I p 269," an accurate reference to a publication of $1594 .{ }^{49}$ In the margins of his copy John Dee mentioned another important source on Petosiris: "He [Petosiris] is highly commended by Julius Firmicus. As is Necepso himself." ${ }^{50}$ Indeed other contemporaries, including Joseph Scaliger, discussed Petosiris and Necepso (also spelled Nechepso) based on the mention of them in Julius Firmicus Maternus's compendium of judicial astrology, Matheseos libri VIII. ${ }^{51}$ Where Simmler garnered the location information he provided is unknown and it is not entirely clear what the "Bibliotheca Carpensi et S. Angeli" designated - perhaps the library of Alberto Pio, Prince of Carpi (1475-1531). ${ }^{52}$ The locations for the manuscripts of Petosiris that Simmler provided did not suffice in any case to bring them to light --neither at the time nor in later periods when the information continued to circulate. We see in this case how Gessner pursued together in his bibliography information about both fragments and manuscripts in the quest to recover ancient writings wherever they might be found.

Gessner, his successors, and readers like John Dee all saw the importance of including in the Bibliotheca the locations of manuscripts when possible, even when they were vague ("somewhere in Italy") or likely flawed, as in the case of the Petosiris entry. Gessner's purpose in the Bibliotheca from the beginning was to facilitate access to manuscripts "hiding in libraries" private and public, so location information was especially valuable. Today we have powerful search engines at our disposal and vast digitized library catalogs of printed books, but we face the same challenges as Gessner did, with tools and scales of information specific to our context. On the one hand manuscripts are still the object of a myriad separate specialized and unconsolidated catalogs. On the other hand digitizations are also scattered across vast numbers of different projects and kinds of institutions throughout the world. A further desideratum specific to digital forms is the need to include metadata about the digitization itself, noting for example that a digitization of a work was re-posted after corrections or changes were made, on a given date. As we come to rely on digitizations as part of the infrastructure of libraries, cataloging could usefully

${ }^{49}$ Jacob Friedrich Reimmann, Idea systematis antiquitatis literariae specialioris sive Aegypticae adumbrati (Hillesheim [Hildesheim]: Ludolphus Schröderus, 1718), 108. The reference is to Reiner Reineccius, Historia Iulia, siue, Syntagma heroicum (Helmstedt: Ambrosius Kierchner, 1594), I, 269.

50 "Valde a Julio Firmico commendatus est. ut et Necepso ipse." Bodleian Arch H.c.7, 550.

${ }^{51}$ On Scaliger's interest see Anthony Grafton, Joseph Scaliger: a study in the history of classical scholarship (Oxford: Clarendon Press, 1983), I, 208-9. Petosiris and Nechepso appear together in two different passages and Petosiris alone in another two in Julius Firmicus Maternus, Matheseos Libri VIII, CPL 0101, LLA 515.1, (Turnhout: Brepols, 2010), electronic resource.

${ }^{52}$ I am grateful for this excellent hypothesis to Anthony Grafton. Alberto Pio gets an entry in the Bibliotheca, f. 18v, for his attack on Erasmus, but with no mention of his library. The same is true of the article in Pieter Bietenholz ed., Contemporaries of Erasmus, 3 (Toronto: University of Toronto Press, 1987), 86-88. But Pio is described as an avid collector of Greek books in Tiraboschi, Storia della letteratura italiana, tome 7, part 1 (Milan: Societa Tipografica dei Classici Italiani, 1824), 235. 
include the date of a digitization as part of the metadata of the item. Indeed the date of consultation which scholars are asked to include in their footnotes (though this protocol has not caught on very well) has no significance except in the context of metadata that explain that a version downloaded before a certain date was different in some specified way from one downloaded after that moment.

The key point here is that libraries, catalogers, and bibliographers perform work that is just as vital today as it was in Gessner's day. They gather and diffuse, and ideally offer critical consolidation of information about where texts can be found in their various forms. We may think that books are no longer at risk of loss thanks to digitization, but Gessner offers us a salutary reminder that a new technology alone cannot ensure the survival of books. Whether manuscript, printed or digitized, books depend on the care of their owners - whether individual or institutional — and their survival benefits especially from long-lasting and well-funded libraries and a cadre of professionals to curate them.

\section{PARATEXTS}

Gessner's Bibliotheca of 1545 was remarkable for providing not only publication details for printed books and location details for manuscripts when possible, but also large excerpts copied from the front matter of many books. Gessner explained in the dedication that "we have diligently copied out all the books of individuals with their beginnings if they were present." 53 The "beginnings" that Gessner mentioned comprised what we would call paratexts, especially those which articulated the purpose and scope of the volume: e.g. prefaces, dedications, and/or tables of contents. These excerpts remained unique to the edition of 1545 and were explicitly dropped from the sequels, because, as Lycosthenes explained in his Elenchus of 1551, "the excessive diligence of the very learned man [Gessner] and the great prolixity of the work were unwelcome to many in this kind of writing." ${ }^{54}$

Whereas a paragraph was all each warranted in later editions, authors of major reference such as Domenico Nani Mirabelli and Vincent of Beauvais warranted 3 full pages in Gessner's original Bibliotheca focused on just one work in each case. Gessner worked from a Basel edition of Vincent's Speculum maius (though there were also other editions). ${ }^{55}$ Gessner began by listing ten works of Vincent each with brief incipit for identification purposes then devoted the rest of the article to the Speculum and its four volumes. He quoted the first twelve lines of the prologue in which Vincent articulated his goal of "reducing into one volume in a kind of compendium and in summary order some flowers chosen according to my talent, from almost all those authors which I was able to

53 "[L]ibros tamen singulorum omnes cum suis initijs, si quae aderant, diligenter exscripsimus." Bibliotheca, sig [*7]r.

54 "Sed cum in eo scripti genere multis ingrata fuisset nimia eruditissimi viri diligentia, tantaque operis prolixitas..." Lycosthenes, Elenchus, sig. b1r.

${ }^{55}$ Gessner did not specify the date, but it is presumably the edition of 1481 listed in the Basel Universitätsbibliothek catalog as place and publisher uncertain but offering Basel: Amerbach as one of the hypotheses. 
read." ${ }^{56}$ Gessner then reproduced the titles of the books in three of the four volumes of the Speculum (naturale, doctrinale and morale with 33, 18 and 3 books respectively). For the Speculum historiale Gessner explained that he would omit the "arguments of the individual books lest I be too prolix." 57 The lists were laid out in various ways even within this one entry, pulled by the competing aims of offering a clear enumeration with a new line for each new section title and of saving space by leaving only a larger gap between titles on the same line. In annotating his own copy of the Bibliotheca, perhaps in view of a later edition which was never prepared, Gessner added paragraph markings to the closing list of chapters within the Speculum morale, evidently preferring the more costly, and more legible, layout over the one that was printed in that section of the entry.

Similarly Gessner devoted three pages to the one work of Domenico Nani Mirabelli-his Polyanthea, frequently reprinted, for which Gessner mentioned editions of Basel 1512 and Savona 1514. First Gessner quoted thirty-two lines from Mirabelli's preface that explained his purpose, sources, and title, then he listed the 308 alphabetical headings in which the work was organized. In this way Gessner helped to circulate even to those who did not own a copy of the Polyanthea a "standard" set of commonplace headings which note-takers could imitate in their own own manuscript notebooks, as I have found in one case for example. ${ }^{58}$ Gessner ended the entry with a paragraph in his own voice, noting that any number of other terms could serve as headings too, but explaining that those should be reserved for a lexicon instead, and pointing out that the Polyanthea offered quotations not only in Latin and Greek, but also in Italian, notably from Petrarch and Date. ${ }^{59}$

Even with more prolific authors Gessner continued to quote large chunks of prefatory statements. After Aristotle (with 38 pages), Jerome and Erasmus are among the longest entries in the Bibliotheca at 13 and 14 pages respectively. In both cases Gessner included lists of contents and long quotations from dedications and prefaces, from editions published in Basel to which he no doubt had ready access given his regular contacts with Basel printers. ${ }^{60}$ Gessner worked from the complete works of Erasmus published in Basel

56 “[V]isum est tandem ..., quosdam flores pro modulo mei ingenii electos, ex omnibus fere quos legere potui, ... in unum corpus voluminis quodam compendio et ordine summatim redigere." Bibliotheca, f. $624 \mathrm{v}$.

57 "Specula historialia, ab initio mundi usque ad sua tempora 1260 historias continent: et in tres partes subdividuntur: singulorum librorum argumenta ne sim prolixior praetereo." Bibliotheca, f. 625v.

${ }^{58}$ See Cambridge University Library, MS Gg.i.28 --a manuscript "theology index" dated 1628 that followed entries in the Polyanthea. The author could have copied them from Gessner instead. This is unlikely in this particular case given the considerable geographic and chronological distance of the manuscript from Gessner's Bibliotheca, but others may have used Gessner's list of the headings in the Polyanthea in similar ways without actually owning the Polyanthea.

${ }^{59}$ Bibliotheca, ff. 215r-216r.

${ }^{60}$ After Zurich where Gessner published 38 books, Basel was the second best represented location where he published 15 books. He was closest to Oporinus who published four of 
in 1540, listing contents and excerpting more than a folio page each from the dedications of the Apophthegms and of multiple editions of the New Testament. ${ }^{61}$ For Jerome Gessner used the complete works published in Basel in 1526 and quoted from a number of prefatory statements composed by Erasmus in that edition. Gessner excerpted savvily to emphasize the nature of each work, its purpose, organization and features (e.g. annotations, commentary, or indexes) and added further assessments in his own voice.

In this way Gessner offered direct insight into the contents and genre of the work and the style of the author. Although Gessner did not discuss his goals in these terms, his detailed information could benefit readers of many kinds. Those who had good access to books could use the Bibliotheca to make informed choices among them, while others could use Gessner's work as a substitute for accessing the books directly. But all this material was excised when the Bibliotheca was expanded and imitated in later works of bibliography, starting in 1551. Gessner's capacious practice of bibliography made the result larger and more expensive than a narrower focus on author, title, and publication/location details which became the norm.

In online cataloging however it is possible to return to Gessner's vision. Edited volumes are now cataloged with their table of contents providing ready access to authors and article titles that were once hidden inside the printed book. Individual chapters within a monograph can also turn up as apparently separate bibliographical entities in searches now, causing confusion if one assumes they are independent publications. Inevitably new capabilities generate new complexities to master.

Another feature facilitated by digital cataloging is a full description of the paratexts in a book-illustrations, indexes, errata, and the like. For a historian of the book a systematic cataloging of paratexts of early books would be a boon. It would require the use of a controlled vocabulary to describe the many kinds of paratexts and negative cataloging would also be necessary, so the record would not simply note the presence of different kinds of paratext, but also assert their absence. With careful cataloging of this type it would be possible to study patterns in the presence of paratexts (e.g. dedications, prefaces, tables of contents, indexes, and errata to name a few) across different time periods, places, languages of publication, publishers, and genres, to mention just a few factors which could be valuably correlated with patterns of paratexts. Given the vast variety of paratexts in early printed books it is unreasonable to expect to list them all, but more systematic attention to the main types of paratext, even within a specific corpus, would be very valuable.

In short bibliography plays a vital role for scholarship, just as it did in Gessner's day; and in the context of increasing digital tools bibliographical practice might expand to

his books and whom Gessner thanked for access to unpublished manuscripts in his editions of Stobaeus (Zurich: Froschauer, 1543), sig. [a7]v, and of Jodocus Willich. Ars magirica hoc est coquinaria (Zurich: J. Gessner, 1563), sig. *1v-2r. For more on this and other such relationships see my "The dedication strategies of Conrad Gessner," 191-92. ${ }^{61}$ Bibliotheca, 197v-204r. 
incorporate some of the concerns present in Gessner which have eroded since his time, including attention to lost works (even in the age of print), to locations of manuscripts and digitizations as well as printed books, and to the presence and absence of paratexts. 
List of figures with captions

Figure 1: A page from Gessner's unpublished "Thesaurus practice medicinae." Zentralbibliothek Zürich, Ms 204a, f. 47r. This work was prepared for print posthumously by Caspar Wolf in 1596 but never printed so the surviving manuscript reveals how it was compiled: by pasting under headings (here diseases for which remedies were collected) slips of paper cut from manuscripts by Gessner and by others (including letters Gessner received) and from printed books. Visible here are passages from a book in German and one in Latin, both of which show signs of strike-out in red pencil likely indicating that the text had been printed from and then discarded, hence available for Gessner to use at no cost.

Figure 2: Conrad Gessner, Bibliotheca universalis (1545), beginning of the dedication. This copy from the Zentralbibliothek in Zurich was Gessner's own copy which he annotated heavily. In these opening lines where he bemoans the many lost libraries he corrected 3000 to 30,000 in the left margin as the size of the library of the Greek grammarian Tyrannion, following information in the Byzantine Suda. [Please crop to use only the top half of the page]

Figure 3: Josias Simmler, Bibliotheca instituta (Zurich: Froschauer, 1574), Bodleian Arch H.c.7, p. 540.

Figure 4: Ibid.p. 307 